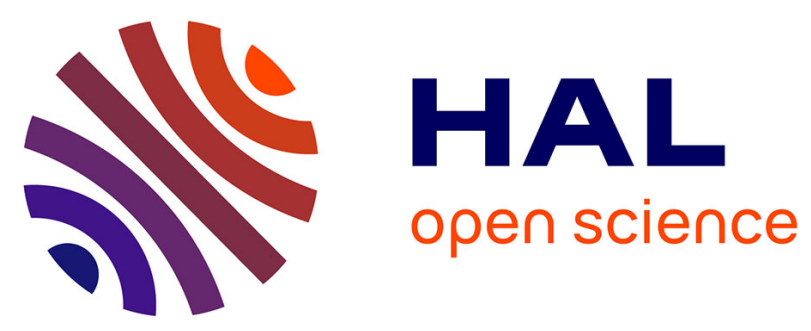

\title{
Multi-Objective Decision Making Optimization of a Residential Net Zero Energy Building in Cold Climate
}

\author{
Fatima Harkouss, Farouk Fardoun, Pascal Henry Biwole
}

\section{To cite this version:}

Fatima Harkouss, Farouk Fardoun, Pascal Henry Biwole. Multi-Objective Decision Making Optimization of a Residential Net Zero Energy Building in Cold Climate. SENSET 2017 - First International Conference on Sensors, Networks, Smart and Emerging Technologies, Sep 2017, Beyrouth, Lebanon. pp.ISBN 978-150906011-5, 10.1109/SENSET.2017.8125044 . hal-01660981

HAL Id: hal-01660981

https://hal-mines-paristech.archives-ouvertes.fr/hal-01660981

Submitted on 11 Dec 2017

HAL is a multi-disciplinary open access archive for the deposit and dissemination of scientific research documents, whether they are published or not. The documents may come from teaching and research institutions in France or abroad, or from public or private research centers.
L'archive ouverte pluridisciplinaire HAL, est destinée au dépôt et à la diffusion de documents scientifiques de niveau recherche, publiés ou non, émanant des établissements d'enseignement et de recherche français ou étrangers, des laboratoires publics ou privés. 


\title{
Multi-Objective Decision Making Optimization of a Residential Net Zero Energy Building in Cold Climate
}

\author{
Fatima Harkouss $^{\mathrm{a}, \mathrm{b}}$, Farouk Fardoun ${ }^{\mathrm{a}}$, Pascal-Henry Biwole ${ }^{\mathrm{b}, \mathrm{c}}$ \\ ${ }^{a}$ University Institute of Technology, Department GIM, Lebanese University, Saida, Lebanon \\ ${ }^{b}$ Université Cote d'Azur, J.A. Dieudonné Laboratory, UMR CNRS 7351, Parc Valrose 06108 Nice, France \\ ${ }^{c}$ MINES Paris Tech, PSL Research University, PERSEE - Center for Processes, Renewable Energies and Energy Systems, CS 10207,06904 Sophia Antipolis, \\ France
}

\begin{abstract}
Zero energy building (ZEB) design is to find the best combination of design strategies that would face the energy performance problems of a particular building. This paper outlines the methodology and the cost-effectiveness potential for optimizing the design of net-zero energy building (NZEB) in a cold climate region in Lebanon; Cedars. Specifically, the non-sorting genetic algorithm (NSGA-II) is chosen in order to minimize thermal, electrical demands and life cycle cost (LCC) while reaching the net zero energy balance; and thus getting the Pareto-front. A ranking decision making technique (ELECTRE III) is applied to the Pareto-front so as to obtain one optimal solution. A wide range of energy efficiency measures are investigated, besides solar energy systems are employed to produce required electricity and hot water for domestic purposes. The results clearly indicate that, for designing a residential NZEB in cold climate, it is essential to minimize the space thermal load through a building envelope with high thermal performance. Envelop high level of insulation is an essential step to decrease the high heating demand. Building thermal loads are decreased by $\mathbf{3 3 . 1 9 \%}$. Moreover the LCC is decreased by $31.09 \%$.
\end{abstract}

Keywords-Optimization; Decision making;Passive stategies; Life cycle cost; Net Zero Energy Building; Renewable energy systems

\section{INTRODUCTION}

Globally, buildings' energy demand is estimated to keep increasing in the next decades. By the end of 2014, buildings (residential, commercial and public) represented about $49 \%$ of the world's electricity consumption, where the residential sector accounts for $27 \%$ of the total electrical use [1].

Nowadays, a new approach is suggested to limit energy consumption and pollution emissions in buildings; Net Zero Energy Building (NZEB) [2].

Building optimization is an effective technique to evaluate design choices and to get the perfect solution for a specific intention expressed as objective functions under several constraints [4]. Multi-objective optimization (MOO) results are sets of non-dominated solutions called Pareto optimal solutions represented as a Pareto frontier [5]. Once the Pareto frontier is obtained, here comes the importance of the multicriterion decision-making (MCDM) process in order to select the final optimal solution among all available possibilities.
In this paper, cost-effective design options for a prototypical residential NZEB in Cedars, a cold climate region in Lebanon, is investigated. First, the base case design conditions, RE systems, and simulation results are described. Then, optimization problem of a wide range of design and operating measures is presented; including wall and roof insulation levels, windows glazing type, window to wall ratio (WWR) in eastern and western facades, cooling and heating set points, PV and SC systems sizing. The optimization is formulated and carried out using "MOBO", a Multi-Objective Building Optimization tool introduced by Palonen et al. (2013) [6]. Besides, in order to obtain a unique solution, the ELECTRE III (Elimination and Choice Expressing the Reality) MCDM technique, developed by Roy [7] is employed. Finally, a set of recommendations is outlined in order to improve the performance design of ZEBs in cold climate.

\section{RESIDENTIAL BUILDING DESCRIPTION}

The optimized building is composed of three floors. Each floor is $205 \mathrm{~m}^{2}$, consisting of two apartments: A \& B, housing a family of four respectively. Building shape, dimensions, orientation and openings are presented in the plan view of Figure I.

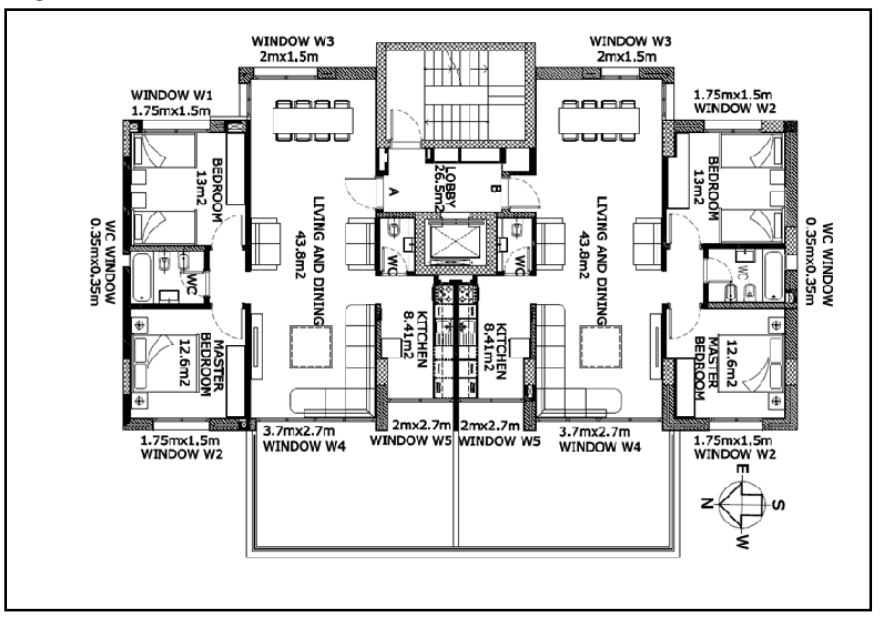

FIGURE I PLAN VIEW OF BUILDING'S TYPICAL FLOORS (WITH TWO APARTMENTS A AND B) 
Eastern and western windows are shaded with opaque roller blinds. Furthermore, cooling loads are covered by air source heat pumps, characterized by a coefficient of performance (COP) equal to 2.9. Heating loads are covered by a natural gas condensing boiler (Efficiency=98.3\%). Systems set points in bedrooms, living rooms and kitchens (cooling only) are set respectively at $24{ }^{\circ} \mathrm{C}$ for cooling and $20{ }^{\circ} \mathrm{C}$ for heating during occupied hours. However, during unoccupied hours, both cooling and heating systems are turned off. The desired relative humidity is set at $50 \%$. The building is considered as tight, so the infiltration rate is equal to 0.38 $\mathrm{ACH}[8]$.

\section{BUILDING RENEWABLE ENERGY (RE) SYSTEMS AND SIMULATION}

\section{A. Maintaining the Solar domestic hot water system characteristics}

In order to cover domestic hot water demands, a flat plate direct active solar domestic hot water system (SDHW) with auxiliary heater inside the tank, located on the house roof, is chosen. The SDHW system is composed of 15 solar collectors (SC) connected in series of total area equal to $31.35 \mathrm{~m}^{2}$. Collectors are south oriented; their slope is approximately equal to the local latitude of Cedars.

\section{B. Base case demands simulation}

Buildings different demands, i.e. electrical, thermal and hot water are simulated using TRNSYS software. The obtained buildings' total annual electrical loads are 61.57 $\mathrm{KWh} / \mathrm{y} . \mathrm{m} 2$. Whereas, heating and cooling loads are 89.63 $\mathrm{KWh} / \mathrm{y} \cdot \mathrm{m} 2$ and $14.42 \mathrm{KWh} / \mathrm{y} \cdot \mathrm{m} 2$ respectively.

\section{Photovoltaic system characteristics}

In order to generate electricity, a photovoltaic (PV) array composed of mono-crystalline silicon modules is used. The array is south oriented and sloped at Cedars local latitude. After the necessary analytical calculation [9], results yield to 90 PV modules (15 in series, and 6 in parallel). The building exploits the utility power grid for storage, delivering energy to the grid when the PV system produces more energy than the building uses and draws from the grid when the PV system produces less energy than the building needs.

\section{Base case electrical and economic simulation results}

After integrating the analytically sized PV system in different models, the annual electric balances, i.e. consumption, generation, and electric flows are summarized in Table I. Besides, the obtained life cycle cost (LCC) for a life period of 20 years and an annual discount rate of $5 \%$ is $181180 \$\left(294.60 \$ / \mathrm{m}^{2}\right)$. It can be noticed that over $40 \%$ of building loads are covered by PV system. The Zero energy balance is attained but with a high amount of "Gains" which represent a loss in terms of cost. The next objective will be to minimize this difference in order to save capital cost of PV. It is better to find the just necessary required size.
TABLE I SUMMARY OF ELECTRICAL BALACES

\begin{tabular}{|c|c|c|c|}
\hline Description & $\begin{array}{c}\text { PV system } \\
\text { output (Before } \\
\text { inverter) }\end{array}$ & $\begin{array}{c}\text { Supplied } \\
\text { from PV to } \\
\text { the building }\end{array}$ & $\begin{array}{c}\text { Supplied } \\
\text { from PV to } \\
\text { the grid }\end{array}$ \\
\hline Value (MWh) & 61.53 & 15.26 & 44.42 \\
\hline Description & $\begin{array}{c}\text { Total building } \\
\text { load }\end{array}$ & $\begin{array}{c}\text { Supplied } \\
\text { from Grid to } \\
\text { the building }\end{array}$ & $\begin{array}{c}\text { Gains } \\
\text { "Load- } \\
\text { generated by } \\
\text { PV" }\end{array}$ \\
\hline Value (MWh) & 37.87 & 22.6 & -21.81 \\
\hline
\end{tabular}

\section{FORMULATION OF THE OPTIMIZATION PROBLEM AND} DECISION MAKING PROCEDURE

\section{A. Objective functions and decision variables}

In general, the electrical consumption is given by equation (1):

Electrical consumption $=$ consumption of $($ cooling + heating +

$$
\text { appliances+ lighting }+ \text { SDHW) }
$$

However, consumption from cooling and heating can be minimized by minimizing the thermal demand. Furthermore, consumption from appliances and lighting is not concerned in this study, although it is recommended to use energy star appliances and adequate lighting to maintain visual comfort and at the same time save electricity. Hence, in this study there are four objective functions to be minimized:

$\mathrm{fl}=\min$ ("Auxiliary electric heater + Pump" consumptions)

$\mathrm{f} 2=\min$ (Thermal demand)

$\mathrm{f} 3=\min$ (Difference between load and generation)

$\mathrm{f} 4=\mathrm{min}$ (LCC)

Table II provides the list of building passive and RE systems decision variables. Furthermore, the implementation costs of different design options are derived from [10], [11], [12], [13] and [14].The optimization problem is constrained by the following condition: the average predicted mean vote (PMV) of the whole building must remain between its acceptable bounds $|\mathrm{PMV}| \leq 0.5$.

TABLE II DESCRIPTION AND DIFFERENT OPTIONS OF DECISION VARIABLES USED IN THE OPTIMIZATION PROBLEM

\begin{tabular}{|l|c|l|c|}
\hline \multicolumn{1}{|c|}{ Description } & Type & \multicolumn{1}{|c|}{ Values } & Step \\
\hline External walls insulation thickness (cm) & D & $1,3,5,7,10$ & - \\
\hline Roof insulation thickness (cm) & D & $1,3,5,7,10$ & - \\
\hline $\begin{array}{l}\text { Type of double glazing: Krypton or } \\
\text { Argon, U-value }\left(\mathrm{W} / \mathrm{m}^{2} . \mathrm{K}\right)\end{array}$ & $\mathrm{D}$ & $0.86,1.4$ & - \\
\hline Cooling set point $\left({ }^{\circ} \mathrm{C}\right)$ & $\mathrm{D}$ & $24,25,26$ & - \\
\hline Heating set point $\left({ }^{\circ} \mathrm{C}\right)$ & $\mathrm{D}$ & 19,20 & - \\
\hline Number of solar collectors in series & $\mathrm{C}$ & 1 to 20 & 1 \\
\hline SDHW pump flow rate $(\mathrm{Kg} / \mathrm{h})$ & $\mathrm{C}$ & 50 to 120 & 5 \\
\hline Number of solar panels in series & $\mathrm{C}$ & 1 to 20 & 1 \\
\hline Number of solar panels in parallel & $\mathrm{C}$ & 1 to 40 & 1 \\
\hline Width window bedroom (m) & $\mathrm{C}$ & 1 to 2 & 0.25 \\
\hline Width window master bedroom (m) & $\mathrm{C}$ & 1 to 2 & 0.25 \\
\hline $\begin{array}{l}\text { Width window Living and dining, w3, } \\
(\mathrm{m})\end{array}$ & $\mathrm{C}$ & 1 to 3 & 0.25 \\
\hline $\begin{array}{l}\text { Width window Living and dining, w4, } \\
(\mathrm{m})\end{array}$ & $\mathrm{C}$ & 1 to 3.7 & 0.25 \\
\hline Width window Kitchen, (m) & $\mathrm{C}$ & 1 to 2 & 0.25 \\
\hline
\end{tabular}

D: discrete, C: continuous 


\section{B. Building optimization tool, Algorithm and Pareto-front}

In this study, the optimization is conducted using TRNSYS coupled with MOBO. The non-sorting genetic algorithm (NSGA-II), developed by Deb et al. [15], is adopted. The used parameters' setting of NSGA are as follows: Population size $=$ 40 , Generation number $=25$, Crossover probability $=70 \%$, Mutation probability $=2 \%[16]$. The MOO results are graphically represented in Figure II. However, in the present work the four-objective optimization generates a fourdimensional (4D) problem space, projected in a bidimensional (2D) graph.

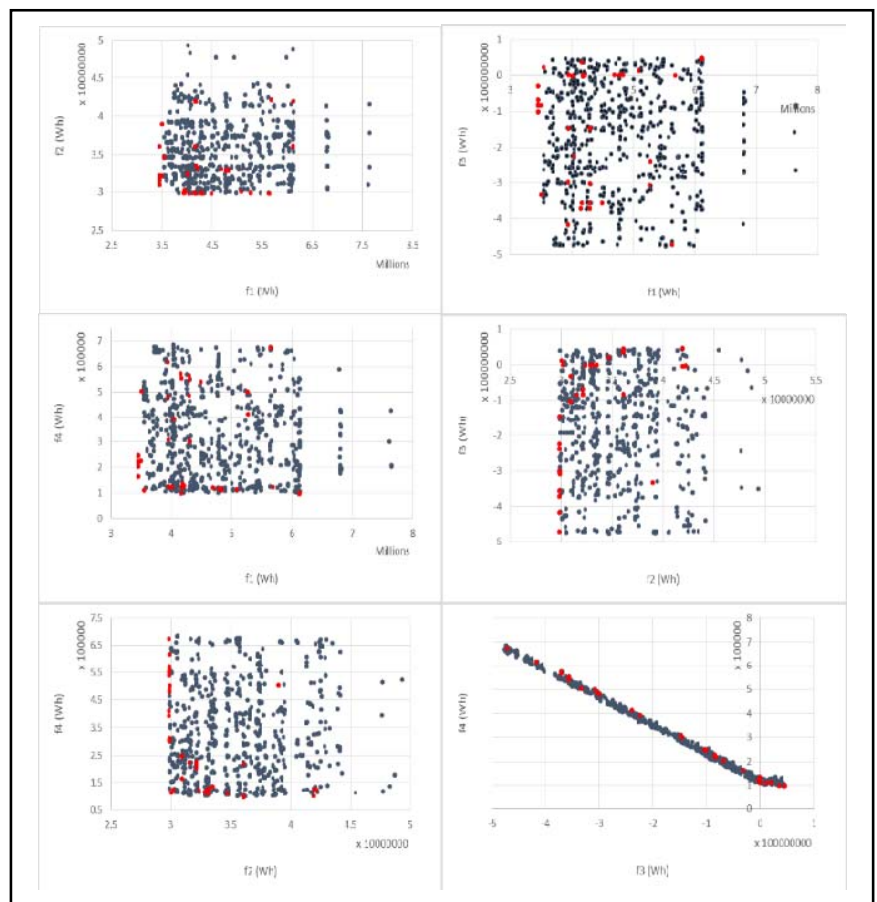

FIGURE II BI-DIMENSIONAL PROJECTIONS OF THE ANALYZED 4D-PROBLEM SPACE (BLUE: BUILDING VARIANTS, RED: PARETO FRONT)

\section{Decision making and sensitivity analysis}

This research employs the ELECTRE III method in order to classify the Pareto front solutions and to choose the most adequate one for each region. Indifference, preference and veto thresholds of ELECTRE III are assigned respectively as follows: $5 \%, 10 \%$ and $30 \%$ relative to the average of each objective function's value for the Pareto front points. The relative weight of each objective function is assigned using the Analytical Hierarchy Process (AHP), proposed by Saaty [17].The best solutions after ELECTRE III ranking are shown in Table III, all together with the difference between the ideal case and the base case. It is noticed that SDHW electric consumption is reduced by $17.91 \%$, thermal energy consumption is decreased by $33.19 \%$ through optimal passive designs compared to the base case, and LCC is reduced by $31.09 \%$. Moreover, the difference between load and generation is decrease to $-0.33 \mathrm{MWh}$ instead of $-21.82 \mathrm{MWh}$ which represent an advantage in terms of initial investment costs of PV system.
TABLE III DIFFERENCES BETWEEN THE BEST SOLUTION BY ELECTRE III AND THE BASE CASE

\begin{tabular}{|c|c|c|c|c|}
\hline & $\begin{array}{c}\text { f1 } \\
\text { (MWh) }\end{array}$ & $\begin{array}{c}\text { f2 } \\
\text { (MWh) }\end{array}$ & $\begin{array}{c}\text { f3 } \\
\text { (MWh) }\end{array}$ & $\begin{array}{c}\text { f4 } \\
(\mathbf{1 0 0 0 \$})\end{array}$ \\
\hline Best solution & 3.94 & 30.19 & -0.33 & 124.84 \\
\hline Base case value & 4.80 & 45.19 & -21.82 & 181.18 \\
\hline \% difference & 17.91 & 33.19 & -98.48 & 31.09 \\
\hline
\end{tabular}

\section{Results and discussion}

Table IV lists NZEBs parameters consequent of the decision making phase. The results clearly indicate that there is a significant potential to improve the energy performance of residential buildings in cold climate of Cedars by using proven passive strategies.

It can be noticed that the necessity to insulate building envelope components is found to be very important, walls and roof insulation is increased up to $10 \mathrm{~cm}$ instead of $5 \mathrm{~cm}$ and $1 \mathrm{~cm}$ respectively. Windows $\mathrm{U}$-value is decreased to 0.86 $\mathrm{W} / \mathrm{m} 2 . \mathrm{K}$ instead of $1.4 \mathrm{~W} / \mathrm{m} 2 . \mathrm{K}$ in order to decrease cold thermal flow from outside to inside the building. Moreover, the optimal WWR in eastern and western façades must guarantee the necessary heat gain from day time's solar radiation. WWR in eastern and western façades are decreased to $21.87 \%$ and $35.15 \%$ respectively. Optimal cooling and heating set points are modified to $25^{\circ} \mathrm{C}$ and $19^{\circ} \mathrm{C}$ respectively in a way to decrease the thermal loads; the occupants comfort is not affected since the PMV is considered as a constraint.

TABLE IV SUMMARY OF THE OPTIMAL BUILDING DESIGN OPTIONS IN EACH REGION

\begin{tabular}{|c|c|c|c|c|c|}
\hline & $\begin{array}{c}\text { Walls } \\
\text { insulation }\end{array}$ & $\begin{array}{c}\text { Roof } \\
\text { insulation }\end{array}$ & $\begin{array}{c}\text { Windows } \\
\text { U-value }\end{array}$ & $\begin{array}{c}\text { Cooling } \\
\text { set point }\end{array}$ & $\begin{array}{c}\text { Heating } \\
\text { set point }\end{array}$ \\
\hline Unit & $(\mathrm{cm})$ & $(\mathrm{cm})$ & $\left(\mathrm{W} / \mathrm{m}^{2} . \mathrm{K}\right)$ & $\left({ }^{\circ} \mathrm{C}\right)$ & $\left({ }^{\circ} \mathrm{C}\right)$ \\
\hline Base case & 5 & 1 & 1.4 & 24 & 20 \\
\hline $\begin{array}{c}\text { Optimal } \\
\text { case }\end{array}$ & 10 & 10 & 0.86 & 25 & 19 \\
\hline & $\begin{array}{c}\text { Solar } \\
\text { collectors }\end{array}$ & $\begin{array}{c}\text { Pump } \\
\text { flow }\end{array}$ & $\begin{array}{c}\text { Number } \\
\text { PV }\end{array}$ & $\begin{array}{c}\text { Eastern } \\
\text { WWR }\end{array}$ & $\begin{array}{c}\text { Western } \\
\text { WWR }\end{array}$ \\
\hline Unit & - & $(\mathrm{Kg} / \mathrm{h})$ & - & $(\%)$ & $(\%)$ \\
\hline Base case & 15 & 70 & 90 & 23.43 & 59.46 \\
\hline $\begin{array}{c}\text { Optimal } \\
\text { case }\end{array}$ & 8 & 115 & 72 & 21.87 & 35.15 \\
\hline
\end{tabular}

\section{CONCLUSION}

The challenge in ZEB design is to find the best combination of design strategies that would face the energy performance problems of a particular building.

In this study, an energy simulation and optimization programs (TRNSYS and MOBO) coupled with a ranking decision making technique (ELECTRE III) are utilized to evaluate the most cost-effective passive strategies and RE systems sizes that should be implemented to achieve a NZE design for a classic residential building located in cold climate of Cedars. In the optimization analysis, a wide range of design and operating measures are considered including wall and roof 
insulation levels, windows glazing type, WWR in eastern and western facades, cooling and heating set points, PV and SC systems sizing.

The optimum design parameters and their corresponding objective functions shows that the annual thermal load and LCC can be decreased by $33.19 \%$ and $31.09 \%$ respectively, compared to the baseline model. Envelop high level of insulation is an essential step to decrease the high heating demands. Besides, WWR of about $21 \%$ and $35 \%$ respectively on eastern and western facades are sufficient to collect the necessary solar radiation and to avoid the excessive outside low temperature.

Future studies may be extended to other passive design parameters, energy efficient systems, and RE systems as well as other objective functions such as the life cycle assessment impact. In addition, the simulation-based sensitivity and uncertainty analyses of the decision maker preferences and design parameters are interesting topics for the future research works.

\section{ACKNOWLEDGMENT}

The authors would like to thank the Lebanese university as well as the association of specialization and scientific orientation for their support.

\section{REFERENCES}

[1] "International Energy Agency Statistics.http://www.iea.org.," 2016. .

[2] S. Pless and P. Torcellini, "Net-Zero Energy Buildings A Classification System Based on Renewable Energy Supply Options," National Renewable Energy Laboratory, Technical NREL/TP-55044586, 2010.

[3] P. Torcellini, S. Pless, M. Deru, and D. Crawley, "Zero energy buildings: a critical look at the definition," Natl. Renew. Energy Lab. Dep. Energy US, 2006.
[4] A. Athienitis and W. O'Brien, Eds., Modeling, Design, and Optimization of Net-Zero Energy Buildings. Ernst \& Sohn, 2015.

[5] B. C. Cheung, R. Carriveau, and D. S. K. Ting, "Multi-objective optimization of an underwater compressed air energy storage system using genetic algorithm," Energy, vol. 74, pp. 396-404, Sep. 2014.

[6] M. Palonen, M. Hamdy, and A. Hasan, "Mobo a new software for multi-objective building performance optimization," in Proceedings of the 13th Internationcal Conference of the IBPSA, 2013, pp. 25672574.

[7] B. Roy, "The outranking approach and the foundations of ELECTRE methods," Theory and Decision, vol. 31(1), pp. 49-73, 1991.

[8] ASHRAE, “ASHRAE Fundamentals Handbook (SI)." 2001.

[9] Alamsyah, TMI, K. Sopian, and A. Shahrir, "Technoeconomics analysis of a photovoltaic system to provide electricity for a houshold in Malaysia. In:The international symposium on renewable energy : environment protection \& energy solution for sustainable development. Kualalumpur,Malaysia,” pp. 387-96, 2003.

[10] M. Krarti and P. Ihm, "Evaluation of net-zero energy residential buildings in the MENA region," Sustain. Cities Soc., vol. 22, pp. 116 125, Apr. 2016.

[11] O. Ibrahim, F. Fardoun, R. Younes, and H. Louahlia-Gualous, "Energy status in Lebanon and electricity generation reform plan based on cost and pollution optimization," Renew. Sustain. Energy Rev., vol. 20, pp. 255-278, Apr. 2013.

[12] C. Milan, C. Bojesen, and M. P. Nielsen, "A cost optimization model for $100 \%$ renewable residential energy supply systems," Energy, vol. 48 , pp. $118-127,2012$.

[13] D. Chung, C. Davidson, R. Fu, K. Ardani, and R. Margolis, "US Photovoltaic Prices and Cost Breakdowns: Q1 2015 Benchmarks for Residential, Commercial, and Utility-Scale Systems," NREL Technical Report, In Preparation, 2015.

[14] "Electricite du liban (EDL)," 2016. [Online]. Available: http://www.edl.gov.lb/.

[15] K. Deb, A. Pratap, and S. Agarwal, "A fast and elitist multiobjective genetic algorithm: NSGA-II," IEEE Transactions on Evolutionary Computation, vol. 6, no. 2, pp. 182-197, Apr. 2002.

[16] N. Delgarm, B. Sajadi, S. Delgarm, and F. Kowsary, "A novel approach for the simulation-based optimization of the buildings energy consumption using NSGA-II: Case study in Iran," Energy Build., May 2016.

[17] R. Saaty, "The Analytical Hierarchy Process-What it is and how it is used," Mathl Modelling, vol. 9, pp. 161-176, 1987. 